\title{
BIODETERIORATION OF CYPERMETHRIN BY LOCAL ISOLATE ISOLATED FROM EGYPTIAN PETROLEUM CONTAMINATED SOIL
}

\author{
Attya H. E. ${ }^{1}$, Roushdy M. M. ${ }^{1},{ }^{*}$ Hassan S. E ${ }^{1 *}$. \\ 1.Department of Botany and Microbiology, Faculty of Science, AL-Azhar University, \\ Cairo, Egypt. \\ * corresponding author: saad_hassan@azhar.edu.eg
}

\begin{abstract}
:
Cypermethrin is a widespread pyrethroid pesticide and is an environmental pollutant because of its toxicity and persistence. Biodegradation of such chemicals by microorganisms may provide a cost-effective method for their detoxification. Sixty-two cypermethrin degrading bacteria were isolated from Egyptian contaminated soil and water samples. The most potent bacterial strain was identified as Ochrobactrum intermedium SP9 based on 16S rRNA gene sequence analysis, as well as several morphological, physiological and biochemical characteristics examinations on classical level. The maximum biodegradation of cypermethrin by bacterial strain SP9 was achieved at $35^{\circ} \mathrm{C}$ and $\mathrm{pH} 7.0$, and the degradation rate reached $69.1 \%$ within 8 days under the optimal conditions. Hence, the Ochrobactrum intermedium SP9 could potentially be used in the future for bioremediation of cypermethrin contaminated soil.
\end{abstract}

Keywords: Cypermethrin, Ochrobactrum intermedium, Biodegradation, pesticide, contaminated soil. 


\section{Introduction}

One of the most strategic problems in our societies is the dangerous accumulation of hazardous wastes compounds in the environment. Many different manufacturers and companies produce hazardous wastes such as pesticides, dyes and heavy metals, etc. Some of these hazardous compounds were accumulated inside the animal and plant tissues, then subsequently transfer to human bodies through ways as eating, drinking and inhalation causing different diseases for human, such as cancer, tumors, respiratory illness, inflammation and other fever, etc (Masindi and Muedi 2018).

Pesticides are a large and varied group of substances that are specifically designed to kill biological organisms including weeds, insects, and rodents. However, the extensive use of pesticides may result in their accumulation in the agricultural products (Tayade $\boldsymbol{e t}$ al., 2013). The problem of the environmental contamination by pesticides goes beyond the locality where it was used. The agricultural pesticides that are exhaustively applied to the land surface travel long distances and can move downward until reaching the water table at detectable concentrations, reaching aquatic environments at significantly longer distances. Therefore, the fate of pesticides has been often uncertain; they can contaminate other areas that are distant from where they were originally used. Thus, decontaminating pesticide-polluted areas was a very complex task (Gavrilescu, 2005). It is interesting to note that insecticides frequently applied in agriculture, mostly belong to the chlorinated hydrocarbon, organophosphate, carbamate and synthetic pyrethroid groups, but their comparative residual effects on microorganisms under a particular soil conditions have rarely been reported (Jayaraj $\boldsymbol{e t}$ al., 2016).

Synthetic pyrethroid insecticides were introduced into widespread use for the control of insect pests and disease vectors more than three decades ago. In addition to their value in controlling agricultural pests, pyrethroids are at the forefront of efforts to combat malaria and other mosquito-borne diseases (Nieradko-Iwanicka and Borzêcki, 2008), and are also common ingredients of household insecticide and companion animal ecto-parasite control products reported (Elsheikha et al., 2011).

Cypermethrin [( \pm ) a-cyano-3-phenoxybenzyl ( \pm )-cis-tran3 (2, 2dichlorovinyl)-2, 2-dimethyl cyclopropane carboxylate] is a photostable synthetic pyrethroid insecticide. It was widely used for control of pests in cotton and vegetable crops, for the treatment of cattle and other livestock and for indoor and outdoor pest control (Lin et al., 2011). It acts on central nervous system of insects by producing hyper excitable state by interacting with sodium channels (Nieradko Iwanicka and Borze^cki, 2008). However, it was also highly toxic to fish and aquatic invertebrates which classified as a possible human carcinogen. It adversely affects the CNS and causes allergic skin reactions and eye irritation in humans (Tallur et al., 2008). Widespread occurrence of cypermethrin has been reported in downstream water bodies and sediments due to runoff and erosion from agricultural fields and nonagricultural applications. Cypermethrin persistence in environment varies from 14.6 to 76.2 days (half-life) depending on physicochemical properties of soil (Weston et al., 2009). 
Microbial activity in soil also plays vital role in determining the fate and behavior of cypermethrin in soil. In the natural environment, hydrolysis of the ester linkage is the principal degradation route and leads to the formation of 3phenoxybenzoic acid (PBA) and cyclopropane carboxylic acid (DCVA) derivatives (Chen et al., 2012). Soil bacteria possess diverse catabolic pathways to degrade pesticides, and this potential can be exploited to design bioremediation strategy to reduce pollution load in contaminated environments. Several bacteria such as Ochrobactrum lupin, Pseudomonas spp., Streptomyces spp., bacillus spp. and Serratia spp. have been isolated from contaminated soil and activated sludge system, and also capable of degrading cypermethrin (Tiwary and Dubey 2016). Degradation pathway of cypermethrin involves initial ester hydrolysis to yield 3-phenoxybenzoic acid (3PBA) which can be converted either to 4-hydroxy-3-phenoxybenzoic acid (Tiwary and Dubey, 2016), or protocatechuate and phenol (Tallur et al., 2008). Microbes isolated from contaminated agricultural soils may possess auxiliary traits such as $\mathrm{N}$ fixation, mineral solubilization, or plant growth regulator production along with biodegradation capacity (Akbar $\boldsymbol{e t}$ al., 2015).

This work aims for (i) isolation and purification of bacterial strains from different soil and water samples and selection of the most potent bacterial strains for biodegradation of Cypermethrin insecticides. (ii) Identification of the most potent bacterial strain by conventional methods, vitek, and molecular methods. (iii) Study the effect of various environmental parameters on biodegradation of cypermethrin insecticides. Finally, evaluation the availability of bacterial strain for bioremediation of cypermethrin contaminated soil.

\section{Materials and methods}

\subsection{Chemicals and media composition.}

Cypermethrin (95\% purity) obtained from (NCIC) El-Nasr-Intermediate Chemicals Company (The Egyptian Armed Forces). This obtained from Ali Akbar group, Pakistan. A stock solution of cypermethrin (95\% purity) was prepared by dissolving $(1,052 \mathrm{ml})$ Cypermethrin in $(100 \mathrm{ml})$ of methanol solution to obtain $(10,000$ $\mathrm{ppm}$ ) and this stock solution was added to desirable concentration in medium as the sole carbon source.

Mineral Salts Medium (MSM) (g/L): $1.0 \mathrm{NH}_{4} \mathrm{NO}_{3}, 1.0 \mathrm{NaCl}, 1.5 \mathrm{~K}_{2} \mathrm{HPO}_{4}, 0.5 \mathrm{KH}_{2} \mathrm{PO}_{4}$, $0.2 \mathrm{MgSO}_{4} 7 \mathrm{H}_{2} \mathrm{O}, 1 \mathrm{~L}$ dis. Water, $\mathrm{pH} 7.0$. For solid plate, $1.5 \%(\mathrm{w} / \mathrm{v})$ agar was added. The media were sterilized by autoclaving at $121^{\circ} \mathrm{C}$ for $20 \mathrm{~min}$ before use.

\subsection{Isolation, purification and identification of Cypermethrin by utilizing microorganisms.}

Three samples were collected from contaminated soil of Misr gas stations at Aga and met ghamer cities, Al-Dakahlia governorate, Egypt, for isolation of the Cypermethrin-degrading bacteria. The samples were collected at summer season of 2017 where the temperature range was $38-40^{\circ} \mathrm{C}$, and the samples were taken from a 
distance of $20 \mathrm{~cm}$ after taking out nearly $5 \mathrm{~cm}$ of the soil superficial. The samples were retained in sterile polyethylene bags, closed strongly and stored at $4^{\circ} \mathrm{C}$ for further study

The procedure used for the isolation of Cypermethrin utilizing microorganisms was carried out by preparation of the previously mineral salt medium, and the selected insecticide Cypermethrin were added separately as a sole source of carbon and energy. This medium was first cooked and sterilized at $121^{\circ} \mathrm{C}$ and 1.5 atmospheric pressure for $20 \mathrm{~min}$. Then this medium was then allowed to cool to about $40^{\circ} \mathrm{C}$ and then supplemented with selected Cypermethrin at different concentrations as a sole source for carbon and energy. One $\mathrm{ml}$ from previous enrichment medium was transferred and dispensed in sterilized Petri dishes left for solidification on each Petri-dish and then spread over the surface of the media by using a sterile glass spreader. After inoculation, the Petri-dish was incubated at $35^{\circ} \mathrm{C}$ for seven days (Chen et al., 1959).

The procedure for the purification of the bacterial isolates under study was carried out by the streak plate method All bacterial colonies of different forms and colors were picked up and reinoculation again onto plates containing the same isolation medium which showing separate growth on solid media. At the end of incubation period, only the growth, which appeared as a separate colony on solid media was picked up and reinoculation again for several consecutive times to ensure its purity. Then the separated colonies were preserved in slants for further work. Purity was checked up microscopically and morphologically (Johnson et al., 1959).

\subsection{Screening for the most potent bacterial isolates concerning the selected Cypermethrin biodegradation activity.}

Screening for potential isolates was carried out by analyzing the growth range of isolate on gradient plate and the concentration of Cypermethrin degradation potential. Gradient plates were prepared by adding A base layer of $15 \mathrm{ml}$ mineral salt medium and setting it in wedge Shape at $30^{\circ} \mathrm{C}$. Another $15 \mathrm{ml}$ of agar containing $50 \mathrm{mg} / \mathrm{L}$ Cypermethrin was poured on set base to make Cypermethrin gradient across the plate surface (Murugesan et al., 2010).

Isolates were streaked along the pesticide gradient and bacterial growth range along the gradient was recorded after incubation. Degradation potential of isolates was determined by the growing of these bacterial strain in mineral salt medium containing different concentrations of Cypermethrin from $(100 \mathrm{mg} / \mathrm{L}$ to $400 \mathrm{mg} / \mathrm{L})$ for 8days. After incubation of residual Cypermethrin concentration, the selection of the most potent bacterial isolate depending on concerning the biodegradation of Cypermethrin insecticide can be resistant to the high concentration of the selected insecticides.

\subsection{Characterization and identification of cypermethrin degrading bacteria.}

A cypermethrin degrading isolate designated as SP9 was showed the highest degradation rate and selected for further study. The purified SP9 was identified on the basis of its morphological characteristics, biochemical tests and 16S rRNA gene sequence analysis. The isolate SP9 was confirmed by 16S rRNA gene sequence. The DNA was extracted and purified using the Qiagen genomic DNA buffer set. PCR 
amplification was performed as described by Mirnejad et al (Mirnejad et al., 2012). The 16S rRNA sequencing was performed by Beijing Liuhe Huada Genomic Company (Beijing, China). The sequences with the highest 16S rDNA partial sequence similarity were selected and compared by CLUSTAL W. Phylogenetic and molecular evolutionary analyses were conducted by MEGA 4.0 software with the Kimura 2paremeter model and the neighbor joining algorithm (Haws et al., 2011). Confidence estimates of branching order were determined by bootstrap resampling analysis with 1000 replicates.

\subsection{Inocula preparation.}

Unless otherwise stated, the inoculants for this experiment were bacteria cultured in a $130 \mathrm{~mL}$ serum bottle containing $120 \mathrm{~mL}$ of PSB medium in a light incubator at $35^{\circ} \mathrm{C}$ and 7500 lux. At the exponential phase (about 2-3 days), the cell pellets were harvested via centrifugation $(5000 \times \mathrm{g}, 10 \mathrm{~min})$, washed 3 times with $50 \mathrm{~mL}$ of $\mathrm{KH}_{2} \mathrm{PO}_{4}$ $\mathrm{K}_{2} \mathrm{HPO}_{4}(0.15 \mathrm{~mol} / \mathrm{L}, \mathrm{pH} 7.0)$, and then suspended in the same phosphate buffer as the inoculants. In order to avoid the effects of hydrolysis and photolysis, each treatment was set in triplicates with non-inoculated samples as control under the same conditions and analyzed in the same manner (Holmstrupet al., 2010). Samples for residual pesticide concentration analysis were collected from the cultures at regular intervals.

\subsection{Optimal conditions for degrading cypermethrin by Ochrobactrum intermedium SP9.}

To determine the optimal conditions for degrading cypermethrin Ochrobactrum intermedium SP9 the single-factor test was designed in this study under different conditions. To confirm the effect of temperatures on the degradation, the media were placed in illuminating incubators at $\left(10,20,25,30,35\right.$ and $\left.40^{\circ} \mathrm{C}\right)$, respectively. To determine the effect of cypermethrin concentrations on the degradation, MSM media were supplemented with cypermethrin ranging in concentration from $(10 \mathrm{mg} / \mathrm{L}$ to 350 $\mathrm{mg} / \mathrm{L}$ ). The media were prepared at different $\mathrm{pH}$ values from (3.0 to 11.0) buffers for the measurement of the effect of $\mathrm{pH}$ values on the degradation (Chowdhury et al., 2008).

The media were prepared using different types of nitrogen sources to confirm the effect of nitrogen sources on cypermethrin insecticide degradation such as $\left(\mathrm{NaNo}_{3}\right.$, $\mathrm{NH}_{4} \mathrm{Cl}_{2}$, Urea, Peptone, Aspartic acid, and Glutamic acid).

Finally, the media were prepared using different types of carbon sources to confirm the effect of different types and concentrations of carbon sources on cypermethrin insecticide degradation such as (Glucose, Maltose, Glycerol, Starch, and Lactose). All experiments were conducted in triplicates. The non-inoculated controls throughout the study were implemented at the same condition in order to exclude the abiotic degradation effect. 


\section{Results and discussion.}

\subsection{Isolation and characterization of cypermethrin degrading bacterium.}

After repeated enrichment and purification processes, we obtained many strains of organisms with different colony from the activated sludge and polluted samples. But the degradation experiments showed that, the isolate (SP9) was possessed the relatively higher degradation, capacity of degrading cypermethrin $(350 \mathrm{mg} / \mathrm{L})$ after incubation for 8 days at $\mathrm{pH} 7.0$ and temperature $35^{\circ} \mathrm{C}$. The isolate (SP9) was utilized cypermethrin as its sole carbon and energy source in MSM (Zhaoet et al., 2013). Thus strain (SP9) was selected and then preserved for further detail investigations. The isolate (SP9) was identified morphologically as a gram-negative, rod shape and the shape of the (SP9) colony grown for 10 days on MSM agar plate, was reddish-brown, smooth, circular, wet, nontransparent, glistening, and with entire margins. SEM observations showed that the cells are ovoid to rod shaped, sometimes even longer, measuring about $1 \mathrm{~mm}$ in size and are motile by means of lophotrichus flagella. The physiological and biochemical characteristics of (SP9) were shown in Table (1) which. The bacterial isolate was appeared as rod shape, negative for Gram reaction, non-spore forming, the oxidase test positive, motile by lophotrichus flagella and can be grown under aerobic condition but can't be grown under strict anaerobic condition. Additionally, 3\% $\mathrm{KOH}$ positive and cytochrome oxidase positive. The production of tryptophanase was positive, while Arginine Dihydrolase, Urease, Gelatinase and $\beta$-Galactosidase were negative. The bacterial cell cannot accumulate the poly $\beta$ hydroxylbutyric acid (PHB) and can't produce any pigments. The bacterial isolate could degrade hydrogen peroxide $\left(\mathrm{H}_{2} \mathrm{O}_{2}\right)$ by producing Catalase enzyme. The bacterial isolate under study can't grow in presence of $\mathrm{NaCl} 8.5 \%$ and can be grown at $25 \mathrm{oC}$ to $40 \mathrm{oC}$ and have the ability of nitrate reduction. This result was agreed with (Schleifer, and Bell, 2009). Bergey's manual of systematic bacteriology. And also agreed with (Saxena et al., 2015). Laboratory Manual of Microbiology, Biochemistry and Molecular Biology. 
Table (1). Physiological and biochemical characteristics for bacterial isolate.

\begin{tabular}{|c|c|c|c|}
\hline Items & Results & Items & Results \\
\hline Gram stain & + & Assimilation of adabic acid & - \\
\hline Cell shape & Rod & Assimilation of phenylacetic acid & - \\
\hline Motility & + & Assimilation of lactose & - \\
\hline Endospore form & - & Assimilation of glucose & - \\
\hline Colony shape & Circular & Assimilation of saccharose & - \\
\hline Colony size & $1 \mathrm{~mm}$ & Assimilation of inositol & - \\
\hline Aerobic growth & + & Assimilation of Manito & - \\
\hline Strict anaerobic & - & Assimilation of sorbitol & - \\
\hline pigment & - & Assimilation of melibiose & - \\
\hline PHB accumulation & - & Assimilation of raffinose & - \\
\hline Growth in Nacl $8.5 \%$ & - & Assimilation of rhamnose & - \\
\hline Growth at temp. $45^{\circ} \mathrm{C}$ & - & Assimilation of arabinose & - \\
\hline $\mathrm{KOH} \mathrm{3 \%} \mathrm{test}$ & + & Hydrolysis of 4-nitrophenyl-D-glucopyranoside & + \\
\hline Catalase & + & Hydrolysis of bis-4-nitro phenyl phosphate & + \\
\hline Oxidase & + & Hydrolysis of Acetamide & - \\
\hline Urea's & - & Hydrolysis of Esculin & - \\
\hline Lipase & + & Hydrolysis of L-proline & - \\
\hline $\mathrm{H}_{2} \mathrm{~S}$ production & + & Hydrolysis of 4-nitro anilide & - \\
\hline Indol production & - & $\begin{array}{l}\text { Hydrolysis of O-nitro phenyl beta-D galacto } \\
\text { pyranosid }\end{array}$ & - \\
\hline Cytochrome oxidase & + & Hydrolysis of p-nitro phenyl acetic acid & - \\
\hline Arginine dihydrolase & - & $\begin{array}{l}\text { Hydrolysis of 4-nitro phenyl beta D, galacto } \\
\text { pyranoside hydrolysate }\end{array}$ & - \\
\hline Gelatinase & - & $\begin{array}{l}\text { Hydrolysis of 4-nitro phenyl beta D,xylo } \\
\text { pyranoside }\end{array}$ & - \\
\hline Lysine decarboxylase & - & Hydrolysis of colistn & - \\
\hline $\begin{array}{c}\text { Ornithine } \\
\text { decarboxylase }\end{array}$ & - & Hydrolysis of esculin & - \\
\hline Antibiotic resistance & - & Hydrolysis of acetamide & - \\
\hline $\begin{array}{l}\text { Assimilation of citric } \\
\text { acid }\end{array}$ & + & Hydrolysis of nitro analide & - \\
\hline $\begin{array}{l}\text { Assimilation of } \\
\text { glycerol }\end{array}$ & + & & \\
\hline $\begin{array}{l}\text { Assimilation of } \\
\text { maltose }\end{array}$ & + & & \\
\hline $\begin{array}{l}\text { Assimilation of } \\
\text { coumaric acid }\end{array}$ & - & & \\
\hline
\end{tabular}

$*_{-}=-$ve test., $+=+$ve test 


\subsection{Confirmed the conventional identification by molecular identification based on $16 S$ rRNA gene sequencing.}

Molecular identification of bacterial isolates showed that the 16S rRNA gene sequences of the isolate (SP9) was identified as Ochrobactrum intermedium. The partial 16S rRNA gene sequences of the isolates were generated and detected as sharp bands at (1500bp) by agarose gel electrophoresis as compared with DNA ladder (marker) (Kumari et al., 2015) The tree based on bacterial 16S rRNA gene sequences (Fig.1) Indicate that these isolates were grouped into Firmicutes (one isolate) and phyla; Gamma prototeobacteria (Shamsa and Akbar et al., 2015).

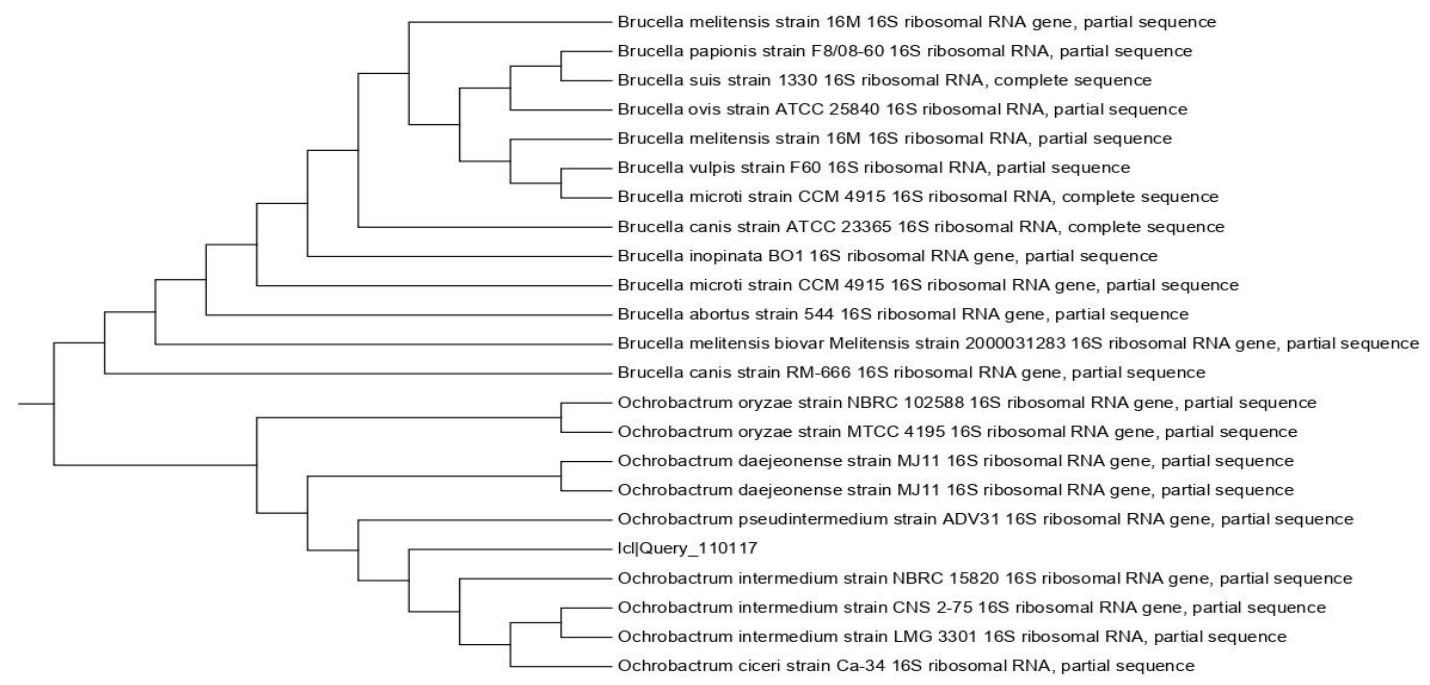

Figure(1) Phylogenetic analysis of $16 \mathrm{~S}$ rRNA sequences of the bacterial isolates with the sequences from NCBI.

\subsection{Study of physicochemical parameters}

\subsubsection{Effect of incubation periods \& incubation conditions on Ochrobactrum intermedium.}

The Ochrobactrum intermedium strain was grown in mineral salt media supplemented with $(3500 \mathrm{ppm})$ of cypermethrin insecticides as a sole of carbon and energy source. Ochrobactrum intermedium strain was grown for 10 days on static and shaking conditions for determination of the best incubation period and incubation condition for biodegradation of cypermethrin (Xiao et al., 2015).

Estimation of cypermethrin residue in culture and compare this result with control to show the best incubation period for biodegradation of cypermethrin by the most potent bacterial isolate Ochrobactrum intermedium (SP9). The highest biodegradation rate under static condition by using Ochrobactrum intermedium (SP9), after 8 days of incubation was $(69.1 \%)$, while the highest biodegradation rate under shaking condition was (49.6\%) after 9 days of incubation of Ochrobactrum intermedium (SP9). these results were shown in Figure (2). This result was agreed with 
(Castro and Tufenkji 2008 1959). who founded that, the optimal incubation period for cypermethrin biodegradation by soil microbe within 8 days under static condition.
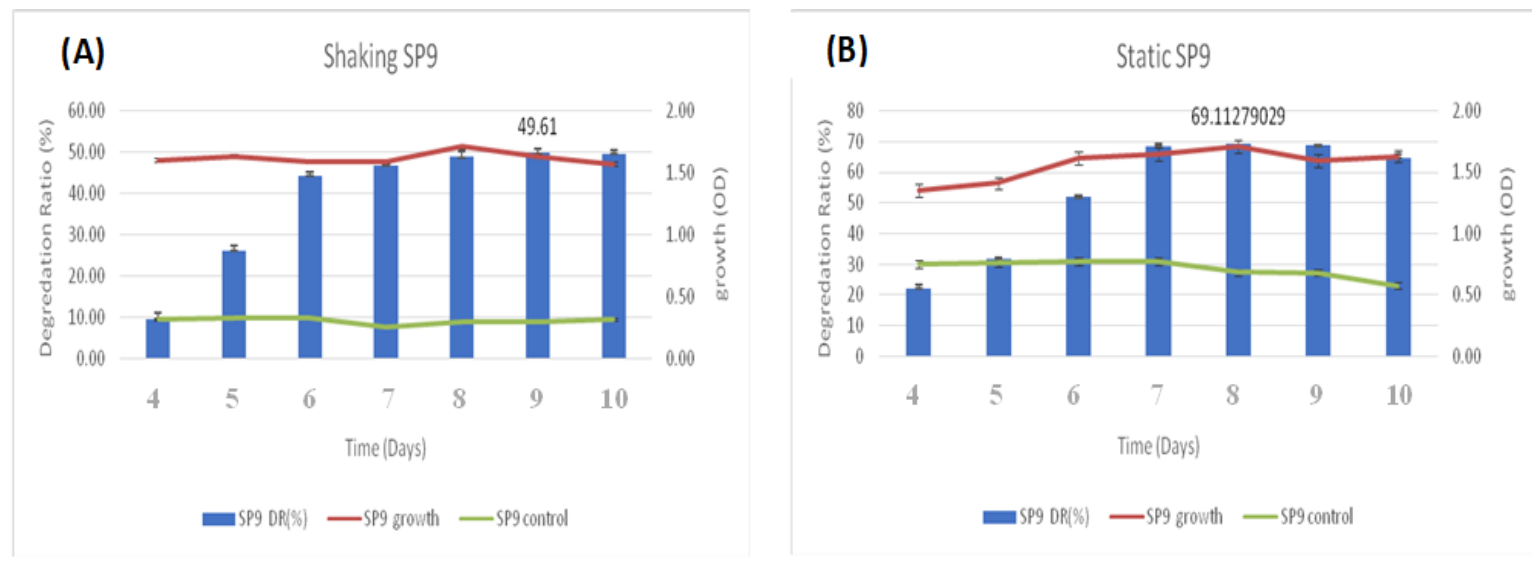

Figure (2). Effect of incubation periods and incubation conditions (shaking (A) and static (B)) on biodegradation of cypermethrin using Ochrobactrum intermedium (SP9).

\subsubsection{Effect of temperature on cypermethrin degradation by Ochrobactrum intermedium}

Cypermethrin was degraded by Ochrobactrum intermedium SP9 during incubation temperatures range from $\left(20^{\circ} \mathrm{C}\right.$ to $\left.45^{\circ} \mathrm{C}\right)$. The cypermethrin residues were detected after 8 days of incubation. The results showed that the degradation rate was $21.95 \%$ and $40.65 \%$ at $20^{\circ} \mathrm{C}$ and $25^{\circ} \mathrm{C}$ respectively. While at higher temperature, i.e. $30^{\circ} \mathrm{C}, 35^{\circ} \mathrm{C}$ and $40^{\circ} \mathrm{C}$, the degradation rate was reached to $48.33 \%, 69.2 \%$ and $53.8 \%$ within 8 days, respectively, but the degradation rate was only $7.7 \%$ when incubated at temperature $45^{\circ} \mathrm{C}$ for 8 days (Figure 3.A). The best temperature for degradation was $35^{\circ} \mathrm{C}$. Similar results were reported by Lin et al., (2011) who reported that, the temperature significantly influenced cypermethrin degradation by Streptomyces sp. strain HU-S-01. Our data also reveal that cypermethrin degradation occurred at $30-35^{\circ} \mathrm{C}$ indicating strain Sp9 preferred relatively high temperature condition. These results were consistent with previous findings of (Chen $\boldsymbol{e t}$ al., 2011a). It is possible that some key enzyme(s) responsible for cypermethrin degradation have their optimum enzymatic activity over such range of temperature. In non- inoculated controls at different temperatures, abiotic degradation was negligible throughout these studies. (Holmstrup et al., 2010).

\subsubsection{Effect of $\mathrm{pH}$ values on cypermethrin degradation in MSM medium by Ochrobactrum intermedium}

The $\mathrm{pH}$ plays an important factor, which significantly effects the degrading ability of bacteria capable of degrading toxicities (Howe et al., 2009) and (Rowland et al., 2011). To determine the effect of $\mathrm{pH}$ value on degradation, MSM medium was 
prepared with different $\mathrm{pH}$ buffers, fortified with $350 \mathrm{mg} / \mathrm{L}$ cypermethrin, and incubated at $35^{\circ} \mathrm{C}$. Eight different $\mathrm{pH}$ values viz., $(3.0,4.0,5.0,6.0,7.0,8.0,9.0,10.0)$ were tested in the optimization experiment. The result showed that the degradation rates were $13.82 \%, 23.3 \%, 34.19 \%, 46.67 \%, 68.3 \%, 60.83 \%, 43.59 \%, 27.35 \%$, respectively (Figure 3.B). The optimal initial $\mathrm{pH}$ value for degradation was between 6.0 and 9.0. Results revealed that SP9 was able to degrade cypermethrin over a wide range of $\mathrm{pH}$. Similar results were reported by Cycoń et al., (2013) who reported that initial pH was significantly efficiently degraded by two Serratia spp., that have rapid degradation rate of cypermethrin at high $\mathrm{pH}$ while it was relatively low at acidic $\mathrm{pH}$. In non-inoculated controls at different $\mathrm{pH}$ conditions, abiotic degradation was negligible throughout the studies (Shen et al., 2013).

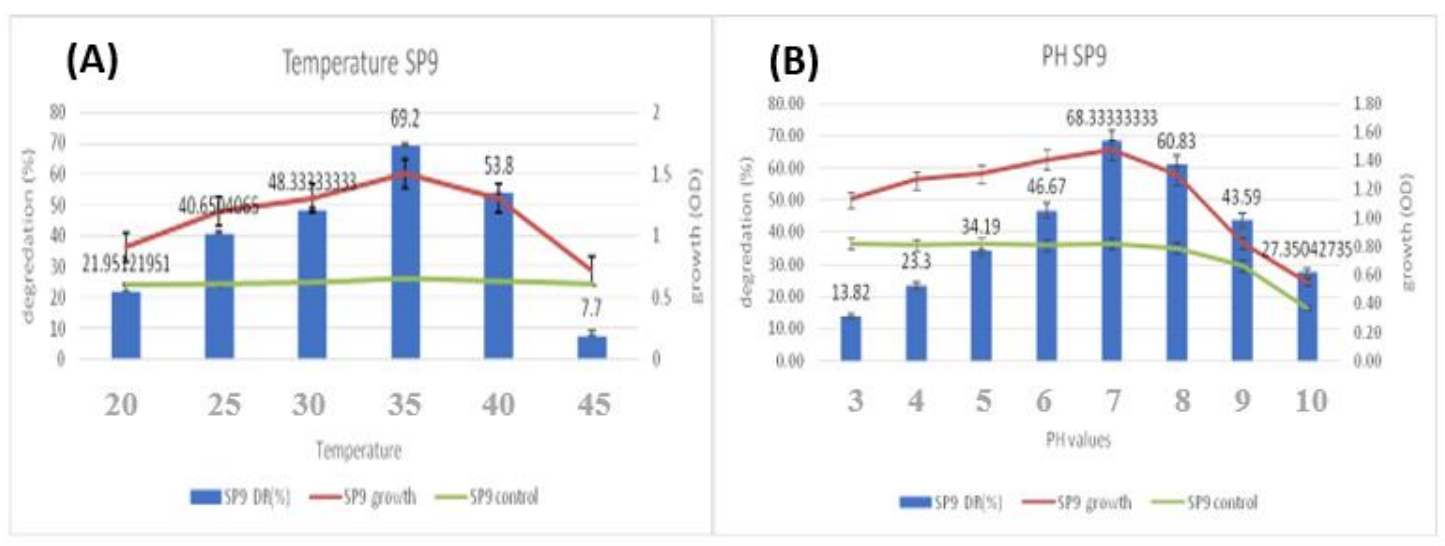

Figure (3). Effect of incubation temperature (A) and $\mathrm{pH}$ values (B) on biodegradation of cypermethrin using Ochrobactrum intermedium (SP9) under static condition.

\subsubsection{Effect of initial concentrations on cypermethrin degradation in MSM by Ochrobactrum intermedium}

Cypermethrin degradation at different initial concentrations by strain Ochrobactrum intermedium (SP9) was investigated. The cypermethrin degradation rates were found to be $(94.7 \%, 93.9 \%, 90.59 \%, 89.6 \%, 80.98 \%, 79.06 \%, 73.44 \%, 68.52 \%$, and $67.48 \%)$ at concentrations range from $(100,200,300,500,1000,1500,2000,2500$, 3000 , and $3500 \mathrm{ppm}$ ), respectively (Figure 4). At low cypermethrin concentrations ranging from 100 to $1000 \mathrm{ppm}$, the degradation rate was reached above $80 \%$ within 8 days of incubation. However, at high concentration (1500 to $3500 \mathrm{ppm}$ ), the degradation rate was reached above $67 \%$ within 8 days. It might be because of the fact that microbial degradation starts slowly and requires an acclimation period before rapid degradation occurs at high concentration. Similar results were reported by Lin et al., (2011) who reported that, the initial concentration of carfofuran was significantly efficiently degraded by Pichia anomala strain HQ-C-01 in contaminated soils. In noninoculated controls at different initial concentrations, abiotic degradation was negligible throughout the studies. 


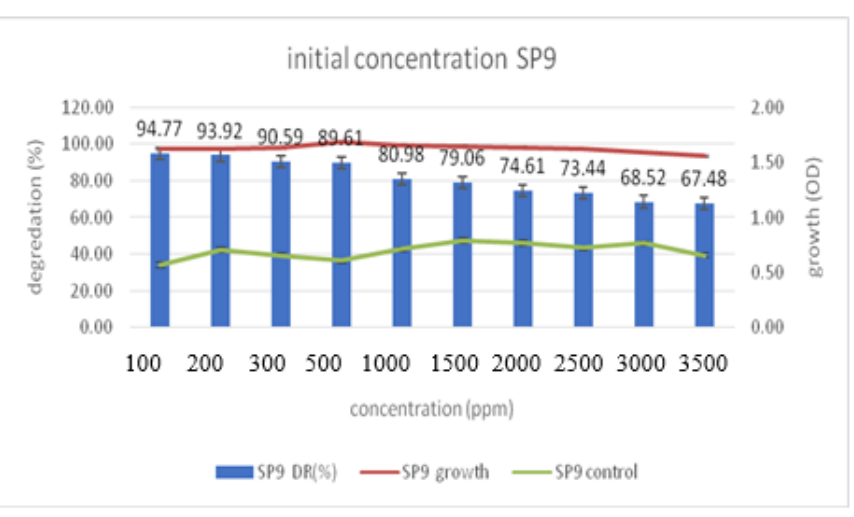

Figure (4). The effect of initial concentrations on biodegradation of cypermethrin by isolate Ochrobactrum intermedium (SP9).

\subsubsection{Effect of different nitrogen sources on cypermethrin degradation in MSM medium by Ochrobactrum intermedium}

The different nitrogen sources play an important factor, which significantly effects the degrading ability of bacteria capable of degrading toxicities. (Wen et al., 2008). To determine the effect of different nitrogen sources on the degradation, MSM medium was prepared with different nitrogen sources, fortified with $350 \mathrm{mg} / \mathrm{L}$ cypermethrin, and incubated at $35^{\circ} \mathrm{C}$-and $\mathrm{pH}$ 7.0. Different nitrogen sources such $\left(\mathrm{Na} \mathrm{No} 3, \mathrm{NH}_{4} \mathrm{Cl}_{2}\right.$, urea, peptone, Aspartic acid, Glutamic acid) were tested in the optimization experiment. The results showed that the degradation rates were $(34.32 \%, 67.49 \%, 65.43 \%, 63.79 \%$, $64.61 \%, 53.91 \%, 60.78 \%$,) respectively (Figure 5). The optimal nitrogen sources for the degradation of cypermethrin was $\mathrm{Na} \mathrm{No}_{3}$ and $\mathrm{NH}_{4} \mathrm{Cl}_{2}$. Results revealed that SP9 was able to degrade cypermethrin over a wide range of different nitrogen sources. In noninoculated controls at different nitrogen sources conditions, abiotic degradation was negligible throughout the studies (Castillo et al., 2006; Wen et al., 2008).

\subsubsection{Effect of different concentrations of carbon source on cypermethrin degradation in MSM medium by Ochrobactrum intermedium.}

The different concentrations of carbon sources also plays an important factor, which significantly effects the degrading ability of bacteria capable of degrading toxicities.To determine the effect of different concentration of carbon source on the degradation, MSM medium was prepared with high concentration of different carbon sources, fortified with $350 \mathrm{mg} / \mathrm{L}$ cypermethrin, and incubated at $35^{\circ} \mathrm{C}$-and $\mathrm{pH}$ 7.0.Different carbon source such (Glucose $0.5 \mathrm{~g} / \mathrm{L}$, Maltose $0.5 \mathrm{~g} / \mathrm{L}$, Glycerol $0.5 \mathrm{~g} / \mathrm{L}$, starch0.5g/L, Lactose $0.5 \mathrm{~g} / \mathrm{L}$ ) were tested in the optimization experiment. The results showed that, the degradation rates were $52.62 \%, 62.62 \%, 67.50 \%, 55.83 \%, 55.83 \%$, respectively (Figure 5). The low concentrations of different carbon sources were increased the degradation of cypermethrin. Results revealed that SP9 used low concentration of carbon source as source of energy to encourage degradation of cypermethrin and SP9 was able to degrade cypermethrin at high range of different low concentrations of carbon sources. In non-inoculated controls at different carbon sources 
conditions, abiotic degradation was negligible throughout the studies (Gurjar and Hamde., 2018).

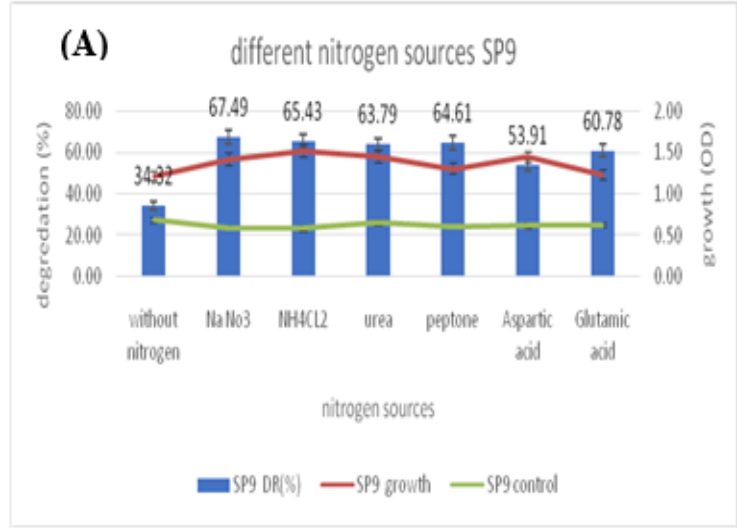

(B) Carbon Sourse Low concentration $(0.5 \mathrm{~g} / \mathrm{L}) \mathrm{HIS7}$

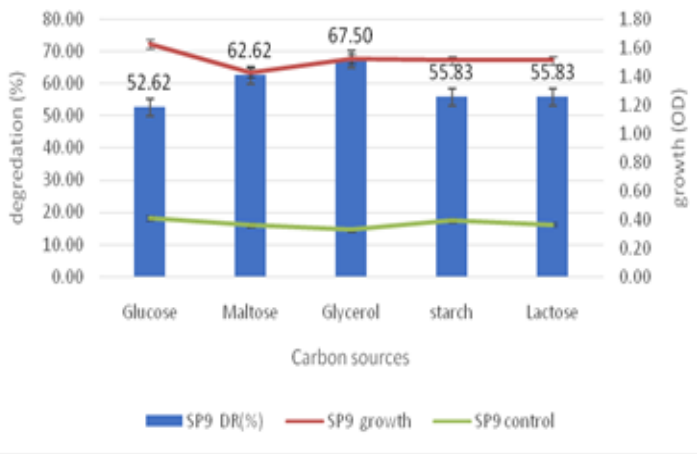

Figure (5). The effect of different nitrogen and carbon sources on biodegradation of cypermethrin by isolate Ochrobactrum intermedium (SP9).

\section{Conclusion}

Ochrobactrum intermedium strain SP9 was isolated from petroleum contaminated soil. This isolate can utilize cypermethrin as sole source of carbon, nitrogen and energy. The optimal incubation condition was carried out under static condition for 8 days. The optimal temperature and $\mathrm{pH}$ value for biodegradation of cypermethrin by strain $\mathrm{SP} 9$ were $35^{\circ} \mathrm{C}$ and $\mathrm{pH}$ 7.0. The degradation rate was reached to $69.1 \%$ within 8 days under static condition. Our results indicated that, the strain Ochrobactrum intermedium SP9 could be an effective choice for the bioremediation of cypermethrin contaminated water and soil. However, further studies as interactions with environment, toxicological aspects, degradation enzymes, biochemical and genetic aspects are still needed before the application in actual field-scale bioremediation.

\section{REFERENCES.}

Armitage, J. P. and Schmitt, R. (1997). Bacterial chemotaxis: Rhodobacter sphaeroide and Sinorhizobium meliloti-variations on a theme. Microbiology, 143(12), 3671-3682.

Akbar, S., Sultan, S. and Kertesz, M. (2015). Determination of cypermethrin degradation potential of soil bacteria along with plant growth-promoting characteristics. Current Microbiology, 70(1), 75-84.

Barber, R. Dand Donohue, T. J. (1998). Function of a glutathione- dependent formaldehyde dehydrogenase in Rhodobacter sphaeroides formaldehyde oxidation and assimilation. Biochemistry., 37(2), 530-537. 
Castro, F. D. and Tufenkji, N. (2008). Role of oxygen tension on the transport and retention of two pathogenic bacteria in saturated porous media. Environmental Science and Technology, 42(24), 9178-9183.

Castillo, M. A., Felis, N., Aragon, P., Cuesta, G. and Sabater, C. (2006). Biodegradation of the herbicide diuron by streptomycetes isolated from soil. International Bio deterioration \& Biodegradation, 58(3-4), 196-202.

Chen, S., Hu, M., Liu, J., Zhong, G., Yang, L., Rizwan-ul-haq, M. and Han, H. (2011). Biodegradation of beta-cypermethrin and 3-phenoxybenzoic acid by a novel Ochrobactrum lupini DG-S-01. Journal of Hazardous Materials, 187(1), 433-440.

Chen, S., Lin, Q., Xiao, Y., Deng, Y., Chang, C., Zhong, G. and Zhang, L. H. (2013). Monooxygenase, a novel beta-cypermethrin degrading enzyme from Streptomyces sp. PloS One, 8(9), e75450.

Chen, S., Geng, P., Xiao, Y. and Hu, M. (2012). Bioremediation of beta cypermethrin and 3-phenoxybenzaldehyde contaminated soils using Streptomyces aureus HPS-01. Applied microbiology and biotechnology., 94(2), 505-515.

Chen, S., Yang, L., Hu, M. and Liu, J. (2011). Biodegradation of fenvalerate and 3phenoxybenzoic acid by a novel Stenotrophomonas sp. strain -ZS- S-01 and its use in bioremediation of contaminated soil. Applied Microbiology and Biotechnology, 90(2), 755-767.

Chen, S., Zhang, Y., Hu, M., Geng, P., Li, Y. and An, G. (2011). Bioremediation of $\beta$-cypermethrin and 3-phenoxybenzoic acid in soils International Symposium on Water Resource and Environmental Protection (Vol. 3, pp. 1717-1721). IEEE. Chen, S., Hu.

Chowdhury, A., Pradhan, S., Saha, M. and Sanyal, N. (2008). Impact of pesticides on soil microbiological parameters and possible bioremediation strategies. Indian Journal of Microbiology, 48(1), 114-127.

Elsheikha, H. M., McOrist, S. and Geary, T. G. (2011). Antiparasitic drugs: Mechanisms of action and resistance. Essentials of Veterinary Parasitology., pp.187.

Gavrilescu, M. (2005). Fate of pesticides in the environment and its bioremediation. Engineering in life Science., 5 (6), 497-526.

Gurjar, M. and Hamde, V. (2018). Biodegradation of Pyrethroid-Cypermethrin using Pseudomonas aeruginosa and detection of its plant growth promoting properties. International Journal of Agriculture, Environment and Biotechnology, 11(3), 549-556. 
Haws, D. C., Hodge, T. L. and Yoshida, R. (2011). Optimality of the neighbor joining algorithm and faces of the balanced minimum evolution polytope. Bulletin of Mathematical Biology., 73(11), 2627-2648.

Holmstrup, M., Bindesbøl, A. M., Oostingh, G. J., Duschl, A., Scheil, V., Köhler, H. R. and Gerhardt, A. (2010). Interactions between effects of environmental chemicals and natural stressors: a review. Science of the Total Environment, 408(18), 3746-3762.

Howe, G. E., Marking, L. L., Bills, T. D., Rach, J. J. and Mayer, F. L. (2009). Effects of water temperature and $\mathrm{pH}$ on toxicity of terbufos, trichlorfon, 4nitrophenol and 2,4-dinitrophenol to the amphipod Gammarus pseudolimnaeus and rainbow trout (Oncorhynchus mykiss). Environmental Toxicology and Chemistry, 13(1),51-66.

Jayaraj, R., Megha, P., \& Sreedev, P. (2016). Organochlorine pesticides, their toxic effects on living organisms and their fate in the environment. Interdisciplinary toxicology, 9(3-4), 90-100.

Kojadinovic, M., Sirinelli, A., Wadhams, G. H. and Armitage, J. P. (2011). New motion analysis system for characterization of the chemosensory response kinetics of Rhodobacter sphaeroides under different growth conditions. Applied and Environmental Microbiology, 77(12), 4082- 4088.

Kumari, L., Tiwari, D. and Nath, G. (2015). Biodegradation of Navy N5RL1 carpet dye by Staphylococcus saprophyticus strain BHUSS X3. Biotechnology. DOI: 10.1007/s, 13. $205-276$.

Liu, S., Yao, K., Jia, D., Zhao, N., Lai, W. and Yuan, H. (2012). A pretreatment method for HPLC analysis of cypermethrin in microbial degradation systems. Journal of Chromatographic Science., 50(6), 469-476.

Lin, Q. S., Chen, S. H., Hu, M. Y., Haq, M. U., Yang, L. and Li, H. (2011). Biodegradation of cypermethrin by a newly isolated actinomycetes HU-S-01 from wastewater sludge. International Journal of Environmental Science \& Technology., 8(1), 45-56.

Mackenzie, C., Choudhary, M., Larimer, F. W., Predki, P. F., Stilwagen, S., Armitage, J. P., Barber, R. D., Donohue, T. J., Hosler, J. P. and Newman, J. E. (2001). The home stretch, a first analysis of the nearly completed genome of Rhodobacter sphaeroides 2.4. 1. Photosynthesis

Research, 70(1), 1941.

Masindi, V., \& Muedi, K. L. (2018). Environmental contamination by heavy metals. Heavy metals, 10, 115-132.

McCoy, M. R., Yang, Z., Fu, X., Ahn, K. C., Gee, S. J., Bom, D. C. and Hammock, B. D. (2012). Monitoring of total type II pyrethroid pesticides in citrus oils and 
water by converting to a common product 3-phenoxybenzoic acid. Journal of agricultural and food chemistry, 60(20), 5065-5070.

Mirnejad, R., Babavalian, H., Moghaddam, M. M., Khodi, S. and Shakeri, F. (2012). Rapid DNA extraction of bacterial genome using laundry detergents and assessment of the efficiency of DNA in downstream process using polymerase chain reaction. African Journal of Biotechnology., 11(1), 173-178.

Murugesan, A. G., Jeyasanthi, T. and Maheswari, S. (2010). Isolation and characterization of cypermethrin utilizing bacteria from Brinjal cultivated soil. African Journal of Microbiology Research, 4(1), 010-013

Nieradko-Iwanicka, B. and Borzêcki, A. (2008). Effect of cypermethrin on memory, movement activity and co-ordination in mice after transient incomplete cerebral ischemia. Pharmacological Reports, 60(5), pp. 699.

Porter, S. L, Wadhams, G. H, \& Armitage, J. P. (2011). Signal processing in complex chemotaxis pathways. Nature Reviews Microbiology, 9(3), 153-165.

Rowland, S., Jones, D., Scarlett, A., West, C., Hin, L. P., Boberek, M., Tonkin, A., Smith, B. and Whitby, C. (2011). Synthesis and toxicity of some metabolites of the microbial degradation of synthetic naphthenic acids. Science of the Total Environment., 409(15), 2936-2941.

Saxena, J., Baunthiyal, M. and Ravi, I. (2015). Laboratory Manual of Microbiology, Biochemistry and Molecular Biology. Scientific Publishers. 1-380.

Schleifer, K. H. and Bell, J. A. (2009). Bergey's manual of systematic bacteriology. The Firmicutes. second edition ed. New York: Springer, 392.

Tayade, S., Patel, Z.P., D. S. Mutkule, D.S., Kakde, A. M. 2013: Pesticide contamination in food: A review. IOSR J. Agri. Vet. Sci., 6(1). 7 -11.

Tallur, P. N., Megadi, V. B. and Ninnekar, H. Z. (2008). Biodegradation of cypermethrin by Micrococcus sp. strain CPN 1. Biodegradation., 19(1), 77-82.

Tiwary, M., \& Dubey, A. K. (2016). Cypermethrin bioremediation in presence of heavy metals by a novel heavy metal tolerant strain, Bacillus sp. AKD1. International Biodeterioration \& Biodegradation, 108, 42-47.

Wang, B., Ma, Y., Zhou, W., Zheng, J., Zhu, J., He, J. and Li, S. (2011). Biodegradation of synthetic pyrethroids by Ochrobactrum tritici strain pyd-1. World Journal of Microbiology and Biotechnology., 27 (10), 2315-2324.

Weston, D. P., Holmes, R. W. and Lydy, M. J. (2009). Residential runoff as a source of pyrethroid pesticides to urban creeks. Environmental pollution, 157(1), 287294. 
Wen-Jun, X. I. E., Jian-Min, Z. H. O. U., Huo-Yan, W. A. N. G. and Xiao-Qin, C. H. E. N. (2008). Effect of nitrogen on the degradation of cypermethrin and its metabolite 3-phenoxybenzoic acid in soil. Pedosphere, 18(5), 638-644.

Xiao, Y., Chen, S., Gao, Y., Hu, W., Hu, M. and Zhong, G. (2015). Isolation of a novel beta-cypermethrin degrading strain Bacillus subtilis BSF01 and its biodegradation pathway. Applied Microbiology and Biotechnology, 99(6), 28492859.

Yin, L., Li, X., Liu, Y., Zhang, D., Zhang, S. and Luo, X. (2012). Biodegradation of cypermethrin by Rhodopseudomonas palustris GJ-22 isolated from activated sludge. Fresenius Environmental Bulletin., 21(2), 397-405.

Zhang, C., Wang, S. and Yan, Y. (2011a). Isomerization and biodegradation of betacypermethrin by Pseudomonas aeruginosa $\mathrm{CH} 7$ with biosurfactant production. Bioresource technology., 102(14), 7139-7146.

Zhang, S., Yin, L., Liu, Y., Zhang, D., Luo, X., Cheng, J., Cheng, F. andDai, J. (2011b). Cometabolic biotransformation of fenpropathrin by Clostridium species strain ZP3. Biodegradation., 22(5), 869-875.

Zhao, H., Geng, Y., Chen, L., Tao, K. and Hou, T. (2013). Biodegradation of cypermethrin by a novel Catellibacterium sp. strain CC-5 isolated from contaminated soil. Canadian journal of Microbiology, 59(5), 311-317.

$$
\begin{aligned}
& \text { تكسير السيبرمثرين بإستخدام عزلة محلية Ochrabacrum intermedium SP9 معزولة } \\
& \text { من تربة ملوثة بالبترول محلة } \\
& \text { حازم عطبه السيد، حمحد محح رشدى، *سعدالدين حسن عفيفى } \\
& \text { قسم النبات و الميكروبيولوجي , كلية العلوم , جامعة الاز هر }
\end{aligned}
$$

البريد الاكتروني للباحث الرئيسي : saad_hassan@azhar.edu.eg

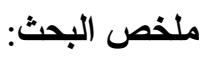

يعتبر الثثيرمثرين من المبيدات الحشرية العضوية الملوثة للبيئة نظراً لسميتة وطول بقائه فى التربة. استخدام

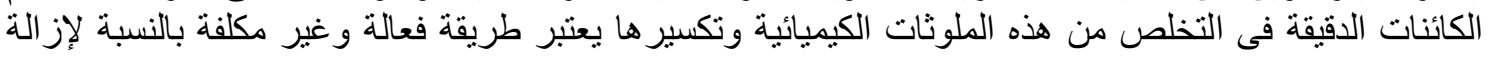

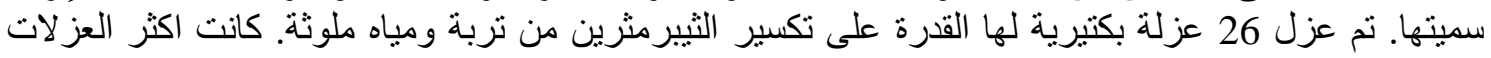

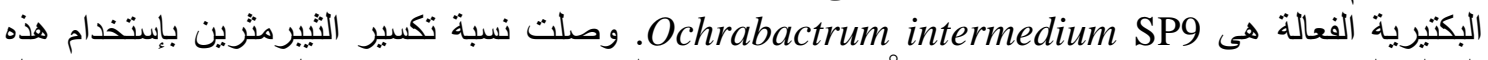

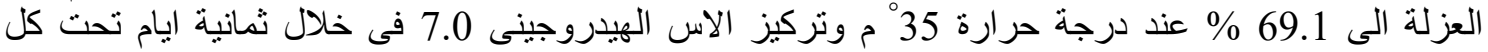
الظروف المتلى للعزلة ومن ثم يمكن استخدام هذه العزلة بفاعلية في المعالجة الحيوية للتربة الملوثة بالتيبير مثرين.

$$
\text { الكلمات المفتاحية: الثيبرمثرين، التكسير الحيوى، المبيدات الحشرية، التربة الملوثة }
$$

